\title{
Danube neighbours' travails
}

\section{London}

THE long-standing dispute between Hungary and Czechoslovakia over the Gabcikovo-Nagymaros hydroelectric scheme has taken a new turn. Angry at the continuation of the Hungarian moratorium on construction, the Czechoslovak engineers are drawing up contingency plans for "technological countermeasures". These, the Hungarians fear, would pose a far greater ecological threat to northern Hungary than even the original plans.

Last May, in response to growing pressure from 'green' groups in Hungary, the Hungarian government declared a moratorium on its side of the joint project, pending yet another expert survey. Czechoslovakia immediately countered with claims for compensation, saying that without the planned dam downstream at Nagymaros in Hungary to catch its tailwaters, the Gabcikovo station in Slovakia could never operate at full power. The Hungarians denied these claims; whereupon the Czechoslovak commissioners switched their attention to Hungary's upstream part of the project - the damming of the river-bed at Dunakiliti (where the Danube flows between Hungary and Slovakia), to divert the river into the new Hrusov reservoir which will supply the Gabcikovo station.

If this reservoir is to be filled by the deadline of December 1990, then the Dunakiliti diversion would have to be completed this October when the hydrological conditions are at their most favourable, with an average flow of about 1,500 cubic metres per second. Once the autumn floodwaters start to rise, the final stage of the diversion operation will have to be postponed, perhaps for a full year, and if the flow exceeds 2,000 cubic metres per second, it may become necessary to destroy the partly finished constructions in order to avoid flooding. Such a postponement, according to Jozef Oblozinski, one of the Czechoslovak government commissioners for the project, could have "catastrophic consequences". Already the Gabcikovo section filling with groundwater, he told the Bratislava daily Pravda and if this is not balanced by Danube water entering from above, the foundations of the dam might start to shift.

The projected Czechoslovak "countermeasures" would mean moving the planned diversion to Somorja, some $14 \mathrm{~km}$ upstream, where both banks of the Danube lie in Slovak territory. If the Czechoslovak official pronouncements are taken at face value, work will begin on the new diversion "if the two governments fail to agree by October". No agreement has, in fact, been reached, but the Hungarians hope that the announced plans were intended more to strengthen the Czechoslovak bargaining position than as a real committment. The proposed new diversion, says Laszlo Udvari, the chief Hungarian commissioner for the dam, would have a major impact on the water table in northwest Hungary and would, moreover, have an adverse effect on shipping conditions. Since the Danube is an international river, he says, Czechoslovak "countermeasures" would raise the controversy from a bilateral one to a matter affecting "all those states involved in Danube shipping, and, indeed, all those who have an interest who have an interest in the politics of Europe". The Hungarian government,
Udvari says, still hopes to solve the dispute by "calm consistent negotiations".

So far, however, there seems little likelihood of such an agreement. Czechoslovakia desperately needs the extra energy the Gabcikovo dam will produce, particularly as its electricity imports from the Soviet Union have been cut for three successive months, and further cuts are expected this winter. The Hungarian government, however, is now committed to go ahead - if at all - only on the basis of a further expert survey and the consensus of public opinion. Even if the Hungarians do, eventually, decide to complete their part of the project, they are not likely to be hurried into meeting the Czechoslovak deadlines.

Vera Rich

\section{MOTIVE POWER}

\section{Powered by hydrogen}

\section{Washington}

THE hydrogen-powered car pictured here hesitated a little before starting on an unexpectedly cold Washington morning, but then successfully carried Senator Tim Wirth (Democrat, Colorado) and Representative Claudine Schneider (Republican, Rhode Island) on a 50-yard trip in front of the Capitol building. The modified Mercedes car, a research vehicle built by Daimler-Benz in West Germany, was brought over to mark the release of a study commissioned by the Washingtonbased World Resources Institute that argues for hydrogen, generated by solar electricity, as the environmentally benign transportation fuel of the future.

By burning hydrogen in a fairly conventional engine, the car emits no carbon dioxide or sulphur dioxides, although it inevitably produces some nitrogen oxides from reactions with nitrogen in the air. But if the hydrogen fuel is made by electrolysing water, using electricity generated by coal or oil, the indirect consequences for the greenhouse effect and for acid rain are as bad as if the car used gasoline. The argument set out in the new report* is that recent efficiency improvements and cost reductions in photovoltaic devices can make electrolysis of hydrogen by solar-powered devices as cost-effective as other suggested petroleum fuel replacements, such as methanol or ethanol.

The prototype car stores enough hydrogen, in a rechargeable metal hydride absorption device, to take it only about 75 miles.

Basing its calculations on a lighter, more fuel-efficient vehicle, the study estimates that about 280 square feet of solar collecting area would be needed to make the fuel for a car that was driven 10,000 miles in a year. This translates into half a per cent of the entire land area of the United States (or one-sixth of New Mexico) to provide for every car in the country.

Wirth and Schneider, after their short trip, praised the West German government for its support of the development work by Daimler-Benz, and castigated US government and industry for their lack of such research. The sudden drop in crude oil prices of a few years ago was accompanied by a similarly precipitous loss of official interest in energy conservation programmes and alternative energy sources, but alarm over global pollution and warming has begun to revive old concerns.

David LIndley

* Solar hydrogen: moving beyond fossil fuels by Joan M. Ogden and Robert H. Williams. World Resources Institute 1989

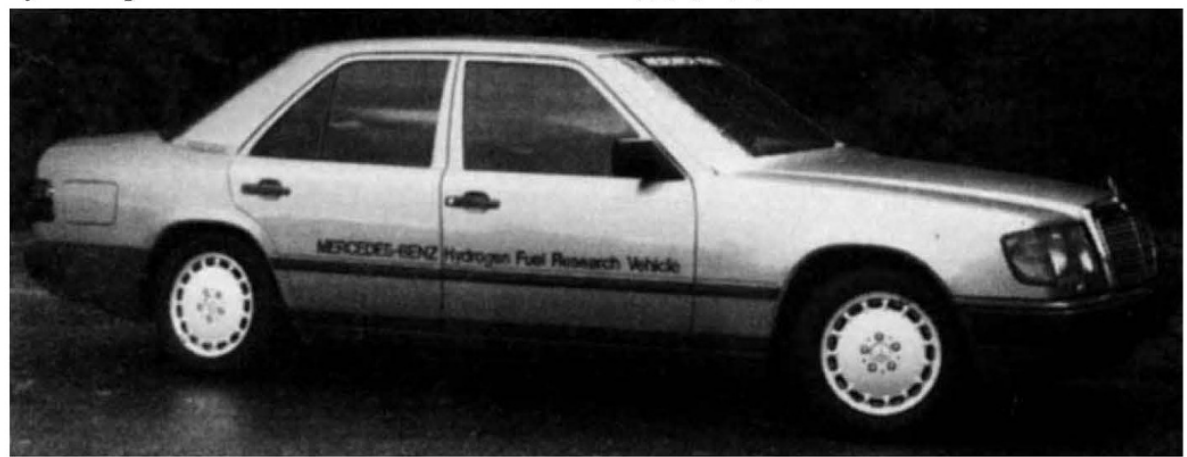

The modified Mercedes $230 \mathrm{E}$ will reach a speed of $105 \mathrm{mph}$ - but has a driving range of only about 75 miles. 